\title{
Impact of Remuneration on Motivation: A Study of Acwell Engineering (PVT)
} LTD Sri Lanka

\author{
Thiththalapitige Natasha ManieshiFonseka
}

Lovely Professional University, Mittal School of Business, Phagwara, Punjab, India. Email: manieshifonseka@gmail.com Tel: +919814271035

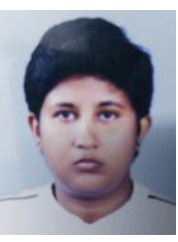

\section{Abstract}

Remuneration appears to be a consequential factor which sways the performance and motivation of the employees of an organization. There are variegated kinds of remuneration policies in disparate organizations. This research anatomizes the remuneration methods and policy of Acwell Engineering (PVT) LTD and how it is influencing the motivation of the employees, and it empirically studies the association between these two variables. Remuneration can be pigeonholed into two parts that is financial and financial remuneration. In addition Chi square, Spearman's correlation, Pearson's rank correlation, econometric modeling and paired samples t test has been used for the empirical analyses. According to the empirical analysis it has been divulged that employee's motivation of Acwell Engineering (PVT) LTD is dependent upon the remuneration methods. This research is hinge on both primary and secondary data. Questionnaire which is powered by Google forms is being used as a primary data collection method. However the other data are secondary data. According to the research it has been divulged that since employee's motivation is swayed by remuneration methods. Acwell Engineering (PVT) LTD has to improvise its remuneration policy and procedures without removing the current remuneration methods.

Keywords: Remuneration, Motivation, Attendance allowance, Over time payment, Net salary, Basic pay.

JEL Classification: M21.

Citation | Thiththalapitige Natasha ManieshiFonseka (2019) Impact of Remuneration on Motivation: A Study of Acwell Engineering (PVT) LTD Sri Lanka. Economy, 6(1): 25-33. History:

Received: 26 April 2019

Revised: 5 June 2019

Accepted: 10 July 2019

Published: 16 September 2019

Licensed: This work is licensed under a Creative Commons

Licensed: This work is
Attribution 3.0 License (cc) Er

Publisher: Asian Online Journal Publishing Group
Funding: This study received no specific financial support.

Competing Interests: The author declares that there are no conflicts of interests regarding the publication of this paper.

Transparency: The author confirms that the manuscript is an honest, accurate, and transparent account of the study was reported; that no vital features of the study have been omitted; and that any discrepancies from the study as planned have been explained.

Ethical: This study follows all ethical practices during writing.

\section{Contents}

1. Introduction

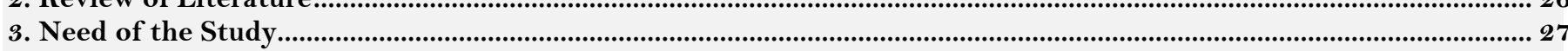

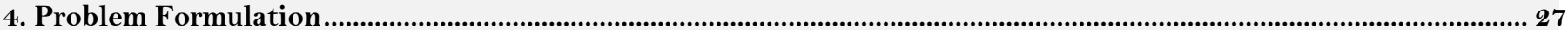

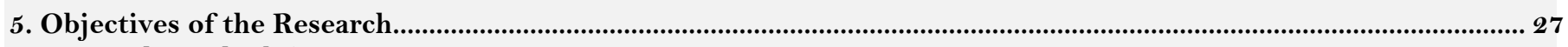

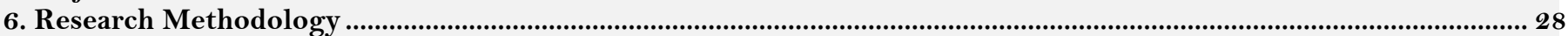

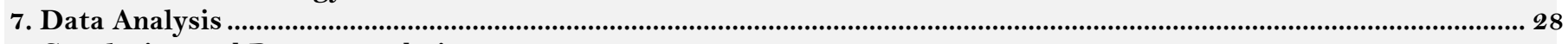

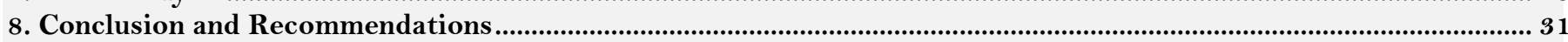

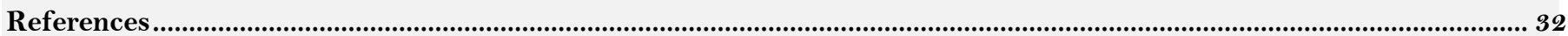




\section{Contribution of this paper to the literature}

The contribution of this paper is based on the results proven with the econometrics models, statistical tests and hypotheses. Since most of the other studies were based on the food company's this research is focused on a construction firm named Acwell Engineering (PVT) LTD Sri Lanka, in order to figure out how much the remuneration policies and methods are affecting the motivation and the performance of the employees in the construction field. Despite of the secondary data primary data are also done a significant role in the study. Through the questionnaire it has been divulged about how much the employees are satisfied with the current remuneration methods and what are they expecting further. In addition to that through the econometric models, paired sample t- tests, chi- square and correlations revealed out the validity of the hypothesis formed and the importance of the remuneration methods in worker's salary. Moreover the results which were obtained from this research can be used for future remuneration policy making process in order to maintain a proper remuneration policy and procedures.

\section{Introduction}

Remuneration means the overall compensation benefits conferred by an executive, but that might include not only the basic salary but also options like monthly/yearly/seasonal bonuses, expense accounts and other forms of compensation. In addition the amount of the remuneration depends upon the various factors. It includes, How much employees are valuable to the company, The job type - this include which type of job the employees is employed with such as full time job or a part time job, Nature of the job - this defines which the nature of the employee's job is. Such as salaried, hourly paid, commission, basic pay, tipped positions. Etc. Remuneration seems to be the mainspring motivation of the employees. Most of the people believe that the senior executives get more remuneration than the others. Nowadays managing human resources seems to be the huge task due to the company profit and competitive environment. Remuneration seems to be the tool which we use to increase production to gain attraction form the employees and strength. And it will increase the public image of the company and the employees turn over. There are various methods of remuneration. It is not only including the monetary rewards but also on-monetary rewards as well. As an example for some jobs they give just the salary and the bonus. But in some other jobs they provide non-monetary benefits along with the monetary benefits. Some people get commissions to especially in sales jobs. There is another type of remuneration that is called as deferred compensation - which is known as the employees earnings sets aside and they can be redeemed at a later date. Moreover some of the benefits can come under the health insurance also. Like gym memberships, providing mobile devices, tabs, cars. In addition to that some company's provide medical benefits to the disables person such as workers compensation. This is specially or the employees who have being disabled during the employment. Moreover there are few more categories as well.

Remuneration policy includes both the financial and non-financial rewards. Therefore it is being categorized into two parts as financial and non-financial. As an organization Acwell Engineering also follows the same procedure in order to attract the employees. Financial rewards include both the direct and indirect rewards. And non-financial methods include both job and environment. Financial rewards are usually known to be the monetary rewards, while the non-financial rewards refer to the rewards which include nonmonetary rewards. It is known to be the salary which comes to the employees hand without adding any extra benefits. In Acwell Engineering the basic pay may varies from one position to another. It may vary from the persons experience as well. There are employees who are for probation period, they are getting a different basic pay. Concerning about the allowances it again includes overtime shifts. Overtime is the payment which the laborers get when they work additional more than the usual working hours. Overtime will not be paid for executive staff; it is paid for non-executive staff only. Usually overtime payment depends upon how much time they work over time. Moreover the overtime payment per hour may vary from one cite to another. Currently they are managing 4 cites namely Mulathiv, Mulankavil, Naiwala, Pillekandura and they are expecting few more cites to undertake. Further Acwell Engineering is providing food allowances and attendance allowances too. Food allowances are usually given for the daily meals of the employees. In addition to that incentives include both the bonuses and the commissions. Bonus means a sum of money which has been added to the employees' wages as a reward for their work performance. But most of the times bonus is paid on festivals like Sinhala and Tamil New Year and Ramadan. But paying a bonus for employees is not a must; it may depend upon the profit of the company. Moreover no one can ask for the bonus. So far Acwell Engineering is not that comfortable with the bonuses and commissions. Indirect Financial benefits - Non financial benefits are the benefits which are known as the non-monetary benefits. It includes holidays and insurance. In Acwell Engineering the employees can get five days off and the employees have to work 25 days per month. Since the construction firms include so many risky works they offer an insurance named workers compensation for the laborers. Non-financial benefits include recognition, performance feedback, good HR policies and safe and secure environment. I have gathered information about these benefits by conducting a random structured interview, for that I have taken a sample of 5 new employees who worked in another company before joining to Acwell and currently working at the head office. I have chosen five new employees because I want to know about the comparison of the remuneration policy of Acwell with the other firms.

\section{Review of Literature}

There are various researches done by various researchers in order to figure out the impact of remuneration on motivation. Gerhart et al. (1995) have stated that response followed by a reward and it is more likely to recur in the future. Moreover Schlosser (2001) has defined that using a fast food organization example, if there are lack of secure employment and the good wages in fast food organization, the managers use more team spirit in order to motivate the employees. Further, it has been defined that the employees work just in order to enhance their profits and that can be considered as the reason for organizations to facilitate them more remuneration policies and methods to the employees. And then again it will increase the productivity of the employees too. The same has been studies by Jenny and Neil (2004). 
Armstrong had described about the effectiveness of remuneration as a means of motivations. Sometimes it motivated employees, contribution systems only takes place when the rewards of them are worthy. Moreover Each and every employee understands the financial rewards and benefits about the organization. They also know about the skills and competences of the system as well. Milan (2002) has proven that the overall remuneration system will always enhance the motivation of the employees who are already working in the organization but also increase the performance of the employees who are not working enthusiastically in the organization. Moreover Jenny and Neil (2004) has proved that remuneration is also very useful in terms of enhancing their self-confidence of the employees and also enhance the standard of living of the employees. Moreover he added that whenever the increment in the salary they can enhanced their prestige and honor. In addition to that they have proven that remuneration can be used as a managerial tool in order to motivate the employees. Durant et al. (2006) shows that the entire employee should get a general compensation for their honest efforts and abilities. But according to them there are different things which are to be clarified before providing the compensation. Those are workers qualification, general economic climate, and specific business conditions, cost of living of the employees, and the qualifications and the productivity of employees and the firm. In addition Perry, Durant et al. (2006) has been proved that the managers have to adopt good remuneration policies in order to increase the performance of the employees. In addition to that Aswathappa (2007) asserted that a behavior which is known to be a rewarding experience is likely to be repeated. Further Armstrong defined that the monetary motivation tool is mostly influencing the employees towards their work. Moreover according to Mathis and Jackson (2008) says that the understanding of motivation is more important in the point of the organization. According to them better understanding of the nature of motivation is important for the firms. Moreover Mathis and Jackson (2008) has defined that remuneration is kind of different from the motivation and it is mostly related with the Hertzberg's hygiene factors. Moreover according to them there are various things which includes in the remuneration methods are salary, bonuses, fringe benefits, etc.

Van Zyl et al. (2010) has proven that there is a positive relationship between the labor productivity and the employee's remuneration and it is proven by Shawn (2011) as well. At the same time Van Zyl et al. (2010) also proven that when the gaps between employee remuneration is regularly proliferating, then it would ultimately enhance the gap and convert the positive relationship between employees' performance and remuneration into negatives. According to the various HR experts, creation of effective rewarding system motivates more employees and it is known to be the motivation to the managers as well. Moreover the study of Chapman and Kelliher (2011) proven that employees motivation usually doesn't come from amount you pay from the organization, but also the better understanding of the individuals. According to the Shawn (2011) has stated that it is necessary to have appropriate rewards in order to satisfy and motivate the employees. Zaman (2011) has stated that human resource basis for an organizations are operating in a dynamic and competitive business environment they need to develop strategies to acquire and retain the competent workforce. Olaoye et al. (2013) had studied about the impact of reward on employee performance in selected manufacturing companies in Ibadan, Oya State, Nigeria.

Hameed et al. (2014) have studied about Impact of compensation on employee performance an empirical evidence of banking sector of Pakistan ; according to the study it has been revealed that compensation has a positive impact on employee performance. In addition to that Edirisooriya (2014) studied about Impact of extrinsic rewards and intrinsic rewards on employee performance and he had proved that there is a positive relationship between extrinsic and intrinsic rewards and employee performance through empirical analysis Moreover Babagana and Dungus (2015) have done their study about Effects of Staff remuneration on the performance of Ramat Polytechnic Maiduguri students for 1995-2011 in Borno state, and they have proved that there is a strong positive relationship between staff remuneration and employee performance.

\section{Need of the Study}

The topic of this study is, The Impact of remuneration on Motivation: a study of Acwell Engineering (PVT) LTD . This measures out the relationship between employee motivation and various remuneration methods used by the Acwell Engineering (PVT) LTD. This research will help to figure out up to which extent the organizations should implement remuneration methods and various recommendations in order to improve the remuneration policy of Acwell Engineering (PVT) LTD. Nevertheless there is are research gaps between 1995 to 2001, 2011 to 2012,2007 to 2010, 2002 to 2004, 2005 to 2006 and after 2015 no researches are found on this topic.

\section{Problem Formulation}

Remuneration seems to be a huge role of an organization. It overall affects both employee performance and employee motivation. Each and every organization use to have a separate remuneration policies in order to attract the employee attention. Acwell Engineering (PVT) LTD also has a remuneration policy which is affecting the motivation and enthusiasm of the employees. This study conducts the research about how remuneration policy of Acwell engineering (PVT) LTD affects the employees' motivation. Are the employees satisfied with the current remuneration policy? And what are their suggestions towards it?

\section{Objectives of the Research}

- To study how the remuneration affects employee motivation in the Acwell Engineering (PVT) LTD.

- To determine the correlation empirically between remuneration and employee motivation based on different motivational theories.

- To understand the remuneration policies and procedures used by Acwell Engineering (PVT) LTD to motivate the employees.

- Suggestions regarding new remuneration strategies. 


\section{Research Methodology}

Each and every research contains a methodology. It defines the way the researcher has adopted to carry out the researches. The research design used over here is a quantitative research design. There are variables like net salary, OT payment, attendance allowance, motivation methods and remuneration. Net salary, OT payment, attendance allowance are quantitative variables, while the motivation methods and remuneration are taken as qualitative variables and it is being measured by both 3 point and 5 point Likert scale using the questionnaire. The research methodology adopted over here is mean, median, mode, Variance, chi square and Spearman's rank correlation method, Pearson's correlation method, Paired sample t test and econometrics modeling. Before applying the tests assumptions for that particular test should be fulfilled. Through calculating the skewness , kurtosis and the variance by dividing it with the standard error leads to find out whether the data is approximately normally distributed or not.

In the paired sample test it figures out if there is a significant effectiveness before and after implementations. Moreover in this research it analyses the correlation between the remuneration and employee motivation. The correlation is analyzed through the SPSS, MS Excel and it is calculated by scaling the responses from the questionnaire provided. Spearman's rank correlation is used when the data is not normally distributed, and when the data is normally distributed Pearson correlation is used.

The sample size of the questionnaire is 50. The questionnaire is powered by Google forms. Simple random sampling is used as the sampling technique. 20 respondents from the head office, 15 from sub-contractors, 15 from administrative staff of 4 cites. Some of the data are being graphically analyzed using different types of graphs like pie charts and bar graphs. In some cases various types of remunerations and its effectiveness is calculated by using the econometrics models, paired sample t test and correlation analysis. Through the correlation it figures out that whether the variables are having a positive or negative impact. There are various types of data collection. Those are primary data and secondary data. Primary data is the data which a researcher gained by themselves. Secondary data is the data which is not collected by them. In this research both the types of data are being used. As a primary method questionnaire is used. As secondary data books, internet, newspapers, previous researchers and reports are being used as well.

\section{Data Analysis}

\subsection{Data Analysis of the Questionnaire (Primary Data)}

From 50 responses $56 \%$ of them were from males and $44 \%$ were from females. One reason for that is mainly construction industry is mostly male dominated in the South Asian region. But in Acwell Engineering (PVT) LTD it seems to be quiet similar because there is just a $12 \%$ gap between them.

Highest percentage $-62 \%$ says that remuneration means making the employees/ labors to work with morale and enthusiasm in order to achieve the organizational objectives. The second highest percentage is $32 \%$. it means that 32 percent says that remuneration means job satisfaction. Rest $6 \%$ is divided with both other two responses. 3 $\%$ says that remuneration means making the employees/ labors to work very hard, and the other $3 \%$ says that remuneration means coming to the job very early and going home very late.

$92 \%$ of responses say that motivation affects the employees/ laborers performance and the rest $8 \%$ says that it doesn't.

According to the responses the highest percentage represents as 30\%. It means employee recognition. Most of the people believe that employee recognition is the best way of motivating the employees. The second highest percentage is $24 \%$, it means making a quality environment. $24 \%$ of people say that making a quality environment is the best way of motivation. The others represent $18 \%, 16 \%$. And the least percentage represents $10 \%$, 10 percent of the people believe that through making flexible working hours is the best way of motivating employees. In addition to that 2 percent says that motivation includes all the ways mentioned over here. 63.3 percent believe that lack of basic pay is the reason for lack of motivation. $26.5 \%$ say that poor working environment is the next reason. 10.2 percent says that lack of leadership is the reason for lack of motivation. There is one thing that should be considered that nobody has responded for sexual harassments. Most of South Asian countries do have sexual harassments in the offices, but if it is hundred present true then it is a good image for Acwell Engineering (PVT) LTD, but most of the times women do not openly say these kind of stuff.

According to the responses $38.8 \%$ says that remuneration or rewards means providing monetary rewards to employees. 30.6\% believe that remuneration means motivating the employees. 18.4 \%says that remuneration means anything that is intended to attract workers attention to work more. The rest 12.2 percent says that remuneration means appreciation of the performance.

Out of 50 respondents 86 percent of them are aware about the remuneration policy in the organization. Rest 14 percent have no idea about that.

"Pay Increases, Increase the Motivation and the Performance of the Employees", Out of 50 respondents 84 percent says that there is are some guidelines which are followed in Acwell Engineering (PVT) LTD when compensating the employees. but 16 percent said no.

"Poor Remuneration of Employees Reduce Their Work Performance".

For the above statement $38.8 \%$ are strongly agreed, $14.3 \%$ are agreed, $12,2 \%$ are neutral, 32.7 percent are disagreeing, $2 \%$ are strongly disagreeing.

"Pay Increase, Increase the Motivation and the Performance of the Employees".

According to the above statement $28.6 \%$ strongly agrees it. $18.4 \%$ agrees, $14.3 \%$ are neutral, $36.7 \%$ are disagreeing, $2 \%$ are strongly disagreeing for the statement.

Out of 50 respondents 46 percent are satisfied with the remuneration policy of Acwell Engineering (PVT) LTD, but 54 percent are not satisfied with it.

More than 20 respondents are saying that salary is important. More than 10 respondents are saying that salary is least important. And nearly 14 respondents have said that salary is the most important. Nearly 7 respondents believed that yearly bonus is the least important, more than 20 respondents believe that yearly bonus is important. But nearly 20 respondents say that yearly bonus is the most important. 10 respondents believe that 
profit sharing is the least important. More than 25 respondents say that profit sharing is important. More than 10 respondents say that profit sharing is the most important. More than 5 respondents say that leave with pay is the least important, while more than 20 respondents believe that leave with pay is important but nearly 20 respondents say that leave with pay is the most important.

According to the data out of 50 respondents 20 said that appraisal is important, 28 said that quality of work life is important and 17 said that prestige is important. Moreover 20 out of 50 respondents said that appraisal is the most important, while other 14 believe in that quality of work is the most important. Moreover 23 other respondents said that prestige is the most important. 9 respondents said that appraisal is the least important while 8 respondents say that quality of work is the least important. 8 people said that quality of work life is the least important. And 10 said that prestige is the least important.

\subsection{Data Analysis of the Secondary Data Collected}

Since all the assumptions for linear regression analysis are met then regression analysis can be formed as followed:

Table-1. Model summary 1.

\begin{tabular}{c|c|c|c|c|c}
\hline Model & $\mathbf{R}$ & R Square & $\begin{array}{c}\text { Adjusted R } \\
\text { square }\end{array}$ & $\begin{array}{c}\text { Std. error of the } \\
\text { estimate }\end{array}$ & Durbin-Watson \\
\hline 1 & & & & & \\
\hline & $.964^{\mathrm{a}}$ & .930 & .924 & 650.678 & 2.553 \\
\hline
\end{tabular}

According to the Table 1 it shows that the value of $\mathrm{R}$ square is 0.930 , which measure the proportion of the variance in the net salary that is predictable from the OT hours.

Table-2. ANOVAb.

\begin{tabular}{c|c|c|c|c|c}
\hline \multirow{2}{*}{ Model } & Sum of squares & Degree of freedom & Mean square & F & Sig. \\
\hline \multirow{2}{*}{$\begin{array}{c}\text { Regression residual } \\
\text { total }\end{array}$} & $7.260 \mathrm{E} 7$ & 1 & $7.260 \mathrm{E} 7$ & 171.476 & $.000^{\mathrm{a}}$ \\
\cline { 2 - 4 } & 5503965.517 & 13 & 423381.963 & & \\
\cline { 2 - 5 } & $7.810 \mathrm{E} 7$ & 14 & & & \\
\hline
\end{tabular}

According to the Table 2 it shows that the $\mathrm{P}$ value of the test is 0.00 but alpha is 0.05 . Since the $\mathrm{P}$-value is less than alpha the null hypothesis will be rejected. Therefore I can say that there is a statistical linear relationship between net salary and OT hours.

Table-3. Model summery 2

\begin{tabular}{|c|c|c|c|c|c|c|c|}
\hline \multirow[b]{2}{*}{ Model } & \multicolumn{2}{|c|}{ Unstandardized coefficients } & \multirow{2}{*}{$\begin{array}{c}\begin{array}{c}\text { Standardized } \\
\text { coefficients }\end{array} \\
\text { Beta } \\
\end{array}$} & \multirow[b]{2}{*}{$\mathbf{t}$} & \multirow[b]{2}{*}{ Sig. } & \multicolumn{2}{|c|}{$\begin{array}{c}\text { Collinearity } \\
\text { statistics }\end{array}$} \\
\hline & B & Std. error & & & & Tolerance & VIF \\
\hline \multirow{3}{*}{$\begin{array}{l}\text { 1. (Constant) } \\
\text { OT }\end{array}$} & & & & & & & \\
\hline & 4049.5694 .170 & 624.805 & & 6.481 & .000 & \multirow[b]{2}{*}{1.000} & \\
\hline & & .318 & .964 & 13.095 & .000 & & 1.000 \\
\hline
\end{tabular}

Since the VIF value is less than 10 multicolinearity is not detected.

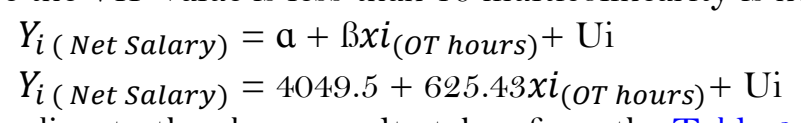

According to the above results taken from the Table 3 it shows that the net salary is dependent upon the OT hours. $X_{i}$ Depicts the (independent variable) as OT, while the $Y_{i}$ (dependent variable) depicts the Net salary. The value of $\mathrm{R}$ square is 0.92 , which means $92 \%$ and other $8 \%$, depicts all the other unexplained factors which influence the changes of the Net salary of employees. The explained $92 \%$ implies that the changes of the net salary are mostly because of the OT hours and payments. The autonomous Net Salary (a) means the salary at which the OT hours are zero. It is 4049.5. $\boldsymbol{\beta}$ Represents the regression coefficient, which implies up to which extent the Net salary will change with respect to the OT hours. Since there is a positive correlation between the two variables it implies that when the OT hours are increasing by 1 hour, the net salary will increase by 625.43 Sri Lankan rupees. As the same goes with the other side, when the OT hours are decreasing by 1 hour then it will decrease the net salary by 625.43 Sri Lankan rupees. According to the econometrics model literally it depicts that when the OT hours are changing by one hour it will change the net salary by 625.43 Sri Lankan rupees.

$\boldsymbol{U i}$ (The stochastic term) represents the all the other factors which affects the changes of the net salary of employees. Since OT payment is done most of the times I have taken it to check whether it is doing a significant impact on worker salary or not. Therefore in order to check it Paired sample T test has been used.

$H_{0}$ : There is no statistically significance difference between without OT and after OT payment of the workers.

$H_{1}$ : There is a statistically significance difference between without OT and after OT payment for the workers. 
Table-4. Paired samples test.

\begin{tabular}{|c|c|c|c|c|c|c|c|c|}
\hline \multirow{3}{*}{$\begin{array}{c}\text { Paired samples t } \\
\text { test }\end{array}$} & \multicolumn{5}{|c|}{ Paired differences } & \multirow[b]{3}{*}{$\mathbf{T}$} & \multirow[b]{3}{*}{ Df } & \multirow{3}{*}{$\begin{array}{l}\text { Sig. } \\
\text { (2tailed) }\end{array}$} \\
\hline & \multirow[b]{2}{*}{ Mean } & \multirow{2}{*}{$\begin{array}{c}\text { Std. } \\
\text { deviation }\end{array}$} & \multirow{2}{*}{$\begin{array}{l}\text { Std. error } \\
\text { mean }\end{array}$} & \multicolumn{2}{|c|}{$\begin{array}{c}95 \% \text { Confidence } \\
\text { interval of the difference }\end{array}$} & & & \\
\hline & & & & Lower & Upper & & & \\
\hline $\begin{array}{c}\text { Pair salary without } \\
1 \text { ot - salary with } \\
\text { ot }\end{array}$ & $\begin{array}{c}- \\
1.890 \\
\text { E3 }\end{array}$ & 546.155 & 141.017 & $\begin{array}{c}- \\
2192.45 \\
1\end{array}$ & $\begin{array}{c}- \\
1587.54 \\
9\end{array}$ & $\begin{array}{c}- \\
13.40 \\
3\end{array}$ & 14 & .000 \\
\hline
\end{tabular}

According to the results from Table 4, the P- value is 0.00 and the alpha is 0.05 . Therefore null hypothesis will be rejected. Which means that there is a statistically significance difference between with and without.

OT payment is in worker's salary. Therefore I can conclude that as a remuneration method OT is playing a significant role in Acwell Engineering (PVT) LTD. Workers Net Salary and the Role of Attendance Allowance.

According to Acwell Engineering (PVT) LTD attendance allowances play a huge role in the worker's salary. Since attendance allowance contains quantitative data it is taken into the research in order to make sure whether the financial remuneration methods are plying a significant role in the worker's salary or not.

Table-5. Paired samples test.

\begin{tabular}{|c|c|c|c|c|c|c|c|c|}
\hline \multirow[t]{3}{*}{ Paired samples t test } & \multicolumn{5}{|c|}{ Paired differences } & \multirow[b]{3}{*}{$\mathbf{t}$} & \multirow[b]{3}{*}{ Df } & \multirow{3}{*}{$\begin{array}{c}\text { Sig. } \\
(\text { 2tailed })\end{array}$} \\
\hline & \multirow[b]{2}{*}{ Mean } & \multirow{2}{*}{$\begin{array}{c}\text { Std. } \\
\text { deviation }\end{array}$} & \multirow{2}{*}{$\begin{array}{l}\text { Std. } \\
\text { error } \\
\text { mean }\end{array}$} & \multicolumn{2}{|c|}{$\begin{array}{l}\text { 95\% Confidence } \\
\text { interval of the } \\
\text { difference }\end{array}$} & & & \\
\hline & & & & Lower & Upper & & & \\
\hline \multicolumn{9}{|c|}{$\begin{array}{c}\text { Pair net salary with allowance } \\
\text { - Net salary without } \\
\text { allowance }\end{array}$} \\
\hline & $\begin{array}{c}950.0 \\
00\end{array}$ & 263.523 & 83.333 & 761.487 & $\begin{array}{c}1138.51 \\
3\end{array}$ & $\begin{array}{c}11.40 \\
0\end{array}$ & 9 & .000 \\
\hline
\end{tabular}

Ho: There is no statistically significance difference between without attendance allowance and after attendance allowance of the workers net salary.

$H_{1}$ : There is a statistically significance difference between without attendance allowance and after attendance allowance for the workers net salary.

Since all the assumptions are met for the paired sample $t$ test, according to the results shown in the Table 5 it shows that the $\mathrm{P}$ value is 0.00 and the value of alpha is 0.05 . So the $\mathrm{P}$ value is less than alpha. Therefore the null hypothesis will be rejected. It means that there is a statistically significance difference between with attendance allowance and without attendance allowance. Therefore I can conclude that attendance allowance make a significance difference in the workers net salary.

Table-6. Correlations.

\begin{tabular}{|c|c|c|c|}
\hline \multicolumn{2}{|c|}{ Correlations } & \multicolumn{2}{|c|}{ Net salary with and without allowance } \\
\hline \multirow{3}{*}{$\begin{array}{l}\text { Net salary with } \\
\text { allowance }\end{array}$} & \multirow{3}{*}{$\begin{array}{c}\text { Pearson correlation } \\
\text { sig. (2-tailed) } \\
\mathrm{N}\end{array}$} & 1 & $.703^{*}$ \\
\hline & & & .023 \\
\hline & & 10 & 10 \\
\hline \multirow[t]{3}{*}{ Allowance } & \multirow{2}{*}{$\begin{array}{l}\text { Pearson correlation } \\
\text { sig. (2-tailed) }\end{array}$} & $.703^{*}$ & 1 \\
\hline & & .023 & \\
\hline & $\mathrm{N}$ & 10 & 10 \\
\hline
\end{tabular}

$H_{0:}$ There is no statistically significance association between attendance allowance and the workers net salary.

$H_{1:}$ There is a statistically significance association between attendance allowance and the workers net salary.

According to the correlation analysis mentioned in the Table $6 \mathrm{P}$ value is 0.023. And the value of alpha is 0.05. So the $\mathrm{P}$ value is less than alpha then the null hypothesis will be rejected. Therefore it signifies that there is statistically significance association between attendance allowances and the worker's salary. The correlation between these two variables is very high. It is 0.703. It implies that whenever the attendance allowances are increasing the workers net salary is also increasing and whenever the attendance allowances are creasing the workers net salary will also decrease. Therefore it reveals that attendance allowance is having a positive impact on workers salary.

\subsection{Empirical Analysis of the Responses of the Questionnaire}

Before checking the chi square test and Spearman's rank correlation the assumptions had to be checked. The values got by dividing skewness and kurtosis are divided by the standard error the values do not lie under the range of +-1.96 . , the data is not approximately normally distributed. 
Table-7. Chi-square tests.

\begin{tabular}{c|c|c}
\hline Test statistics & Remuneration methods & Motivation \\
\hline Chi-square & $12.640^{\mathrm{a}}$ & $35.280^{\mathrm{b}}$ \\
\hline Df & 5 & 1 \\
\hline Asymp. sig. & .027 & .000 \\
\hline
\end{tabular}

\section{$H_{0:}$ Motivation is independent of remuneration methods.}

\section{$H_{1:}$ Motivation is not independent of remuneration methods.}

In the above Table 7 had given the $\mathrm{P}$ value as 0.00 and alpha is 0.05 . So the $\mathrm{p}$ value is less than alpha. Therefore the null hypothesis will be rejected, which, means that motivation of the employees is dependent upon the remuneration methods in Acwell Engineering (PVT) LTD.

Table-8. Nonparametric correlations

\begin{tabular}{c|c|c|c}
\hline Spearman's rho remuneration methods correlation coefficient & Remuneration & Motivation \\
\hline & Sig. (2-tailed) & 1.000 & .212 \\
\cline { 3 - 4 } & $\mathrm{N}$ &. & .140 \\
\cline { 3 - 4 } & & 50 & 50 \\
\hline Motivation & Correlation coefficient & & 1.000 \\
\hline & Sig. (2-tailed) & .212 &. \\
\cline { 3 - 4 } & $\mathrm{N}$ & .140 & 50 \\
\hline
\end{tabular}

Spearman's rank order correlation which mentioned in Table 8 is used in order to figure out the association between the remuneration methods and the motivation of the employees.

$H_{0}$ : There is no negative association between the remuneration methods and motivation of the employees.

$H_{1}$ : There is a negative association between the remuneration methods and motivation of the employees.

In the Table 8, the $\mathrm{P}$ value of the test is 0.140 , but alpha is 0.05 . So the p value is greater than alpha. Therefore the null hypothesis will be accepted, which means that there is a positive association between the remuneration methods and employee motivation in Acwell Engineering (PVT) LTD. So it has been figured out that there is a positive impact on remuneration on motivation of the employees in Acwell Engineering (PVT) LTD.

\section{Conclusion and Recommendations}

According to the questionnaire almost all the respondents have submitted their responses for all the questions except one. Concerning about the staff of Acwell Engineering (PVT) LTD most of them have suggested to increase their basic pay. Some of the employees has suggested to increase the quality of the environment in the office premises. Moreover some employees has suggested to have a flexible working hours. According to the interview they have suggested that they should have proper working hours like 8 to straight 5 . Not more than that. Concerning about the questionnaire still there are few more people who are not aware about the remuneration policy of Acwell Engineering Further according to the data analysis it has been revealed that irrespective of other remuneration methods OT payment is playing a significant role in the workers payment. Furthermore more than half a percent of people are not satisfied with the current remuneration policy of Acwell Engineering Moreover most of the employees are disagree with the statement "Pay increases, increases the motivation and the performance of the employees." But at the same time most of the people believed that motivation affects the performance of the employees. According to the data it shows that 86 percent of people are aware about the remuneration policy of Acwell Engineering, but only 84 percent were known about the guidelines. It is contra dictionary. Most of the staff of Acwell Engineering said that they need more employee recognition at the work place. Concerning about the responses it has been revealed that nobody hasn't face any sexual harassments throughout their work hours. Remuneration can be monetary or non-monetary, methods, but in Acwell Engineering most of the employees prefer monetary benefits than the non-monetary ones. And most of the employees believed that remuneration is affecting the performance of the employees directly. Furthermore most of the employees prefer leave with pay and yearly bonus as their financial remuneration. Among the employees they prefer prestige as their non-financial remuneration method. According to the empirical data analysis from the responses it has been shown that remuneration methods and motivation of the employees are dependent among each other Moreover the correlation analysis shows that there is a low positive correlation between the remuneration methods and the employee motivation. Which means that when then remuneration methods are increasing enough it will increase the motivation of the employees, while when the remuneration methods are decreeing it will decrease the employee motivation too. Overall it defines that there is a positive impact of remuneration on motivation in Acwell Engineering (PVT) LTD.

Acwell Engineering (PVT) LTD seems to be a leader in the construction industry in Sri Lanka. In this research it analyses about how the various remuneration methods in the remuneration policy of Acwell Engineering are affecting the motivation of the employees and the workers. Remuneration methods can be either financial or non-financial. Concerning about the responses taken out from the questionnaire, it clearly shows that most of the people are more interested in monetary benefits than non-monetary benefits. But at the same time some people are concerned with non-monetary benefits like employee recognition. After doing this study recently I have got to know that employees are highly affected through the remuneration methods. They are looking for it. According to the questionnaire the employees and the staff of Acwell Engineering strongly believe that motivation is affecting the employee performance and poor remuneration methods will reduce the employee and workers motivation. Moreover according to the econometrics analysis it is proven that OT hours and OT 
payments is playing a significance role in the remuneration methods which the Acwell Engineering (PVT) LTD has adopted. Moreover it has proved using Paired sample $t$ test also. After concerning about the responses of the questionnaire it has been revealed that the motivation of the employees/ workers in Acwell Engineering is dependent upon the remuneration methods. But the main problem found out in the overall study is most of the people are not satisfied with the current remuneration policy of Acwell Engineering. The suggestions for this are mentioned in the recommendation chapter. According to the correlation analysis it shows a low positive correlation between the remuneration methods and the employee motivation. The degree of association of these variables are low, but it is having a positive impact on employee motivation ; whenever the remuneration methods are increasing the motivation will be increased ,and respectively when the remuneration methods are decreasing then the motivation will also be decreased. In fact there might be some other factors which will increase the motivation. Or else some people might not be aware about the remuneration methods or remuneration policy, or else some of the answers which the people were looking for night not be included in the choices in the questionnaire. In the questionnaire 30 present of the people believe that employee recognition is the best remuneration method which will enhance the motivation of the employees. So it is known to be a non-financial remuneration method. But in the same questionnaire they are proving some contradicting results. In another question they wanted an increase in basic pay as well. So if we combine these two results it clearly shows that they are concerning about both the financial and non-financial remuneration methods. In addition to that nearly half of the respondents believe that prestige of the employees/ workers are the most important method of non-financial remuneration. Irrespective of that some other employees believe that leave with pay is the most important financial remuneration method out of others. But from the organizational point of view it is not that fair enough to pay salary on leave. Nevertheless from the employees' side it is a good benefit. It would be much fair enough if the employees are in a financial hardship. But for that the organization has to first identify the reasons and find out the reasons thoroughly. Moreover since attendance allowance seems to be a quantitative / monetary remuneration method I have analyzed the effectiveness of attendance allowance on the employee's salary. After applying the paired sample $t$ test it clearly proved that there is a statistically significance difference between the salary of the employees with and without the attendance allowance. In addition to that since the data is approximately normally distributed the Pearson's correlation method is used. Through the test it has found that there is a high correlation between attendance allowances and the salary of the employee. This means that when the attendance allowance is increasing then the salary of the workers will also be increased, and when the attendance allowance is decreasing then the salary of the worker will also be decreased. Since more than half of the employees are not satisfied with the current remuneration policy of Acwell Engineering (PVT) LTD. It is better to concern about non-financial remuneration methods in order to improve the motivation of the employees in Acwell Engineering.

After concerning about all the information and the data I would like to suggest some ideas in order to increase the motivation of the employees through various remuneration methods in Acwell Engineering (PVT) LTD. Acwell Engineering (PVT) LTD has to concern more about the remuneration policy since the employees are not satisfied with it. Moreover the degree of association between remuneration methods and employee motivation is quiet low. That might be a reason for dissatisfaction of the remuneration policy. But according to the responses more of the Acwell Engineering (PVT) LTD employees are expecting on-monetary remuneration methods. So from the company point of view it is easier since the non-monetary methods don't cost at all. More of the employees are concerned with flexible working hours like 8 to 5 . In addition to that some of the employees need more recognition inside the organization. Further some of them are requesting for a quality environment. In addition to that some of the employees are requesting a feedback procedure from the employer, so that the employees can perform more in the organization. But they prefer a direct feedback procedure. According to my opinion I would like to suggest that the company should improvise some non-monetary remuneration methods In the quantitative analysis it has been proven that attendance allowance and OT payment is doing a significance role in the worker's salary. Therefore I would recommend that these allowances should not be cut in the future also. And they should implement new beneficial schemes which are having a significant impact on the worker's salary. Concerning about the monetary benefits most of the employees are expecting an increase in the basic pay and more pensionable schemes, respecting authorities of Acwell Engineering (PVT) LTD should concern about this as well. In addition none of the employees in Acwell Engineering (PVT) LTD has been affected with sexual harassments. This is a very good positive aspect and a good image for the organization too. Moreover since some of the employees are not aware about the remuneration policy. Moreover some of the employees are answered as NA in the suggestion field, so then again it might be a reason for non-awareness about the remuneration policy. Respective authorities should make aware the employees about the remuneration policy after employing them in the organization and they should implement new schemes which will enhance welfare of the employees. Moreover it is better if they could enhance the working environment, flexible working hours, employee's recognition and basic pay because motivation of the employees will directly affecting the productivity of the organization.

\section{References}

Aswathappa, K., 2007. Human resources and personal management. 4th Edn., New Delhi: Tata - McGraw Hill.

Babagana, A. and B. Dungus, 2015. Staff remuneration and the performance of ramat polytechnic Maiduguri students from 1995 to 2011. European Journal of Research and Reflection in Management Sciences, 3(5): 1-10.

Chapman, J. and C. Kelliher, 2011. The influences on reward mix: Reward consultants' oerspectives. British Journal of Industrial Relations, 33(2): 121-139.

Durant, R.F., R. Kramer, J.L. Perry, D. Mesch and L. Paarlberg, 2006. Motivating employees in a new governance era: The performance paradigm revisited. Public Administration Review, 66(4): 505-514.Available at: https://doi.org/10.1111/j.1540$6210.2006 .00611 . \mathrm{x}$.

Edirisooriya, W.A., 2014. Impact of rewards on employee performance: With special reference to electri co. Reshaping Management and Economic Thinking through Integrating Eco-Friendly and Ethical Practices Proceedings of the 3rd International Conference on management and economics. Faculty of Management and Finance, University of Ruhuna, Sri Lanka.

Gerhart, B., H.B. Minkoff and R.N. Olsen, 1995. Employee compensation: Theory, practice, and evidence. Ithaca, NY : Cornell University, School of Industrial and Labour Relations, Centre for Advanced Human Resources Studies. 
Hameed, A., M.K. Ramzan, G. Ali and M. Arslan, 2014. Impact of compensation on employee performance (Empirical evidence from banking sector of Pakistan). International Journal of Business and Social Science, 2(2): 27-32.

Jenny, W. and R. Neil, 2004. OCR business studies AS: New edition. England: Oxford University Press. pp: 172-183.

Mathis, R.L. and J.H. Jackson, 2008. Human resource management. 12th Edn., South-Western: Thomson. pp: 592.

Milan, K., 2002. Management consulting. A guide to the profession. 4th Edn., New Delhi: Bookwell Publishers. pp: 196-198.

Olaoye, B.O., M.A. Adeyemi and A.S. Sajuyigbe, 2013. Impact of job satisfaction dimensions on job performance in a small and medium enterprise in Badan, South Western, Nigeria. International Journal of Arts and Commerce, 2(2): 31-45.

Schlosser, E., 2001. Fast food nation: The dark side of the all American meal. United States: Agribusiness, Houghton Mifflin Harcourt Publishers. pp: 571-574.

Shawn, M.C., 2011. Turnover prediction using attitudes towards benefits, pay, and pay satisfaction. Baltic Journal of Management, 32: 196200.

Van Zyl, L.E., E. Deacon and S. Rothmann, 2010. Towards happiness: Experiences of work-role fit, meaningfulness and work engagement of industrial/organisational psychologists in South Africa. SA Journal of Industrial Psychology, 36(1): 1-10.Available at: https://doi.org/10.4102/sajip.v36i1.890.

Zaman, K., 2011. Impact of tangible and intangible rewards on organizational commitment: Evidence from the textile sector in Pakistan. American Journal of Industrial and Business and Management, 5: 327- 334. 